\title{
EU MIGRATION POLICY AND MIGRANT HUMAN RIGHTS: THE PROTECTION AND NEGATION OF LIFE AT EU BORDERS
}

\author{
DANIELA LO COCO ${ }^{1}$
}

\begin{abstract}
This article addresses the contradiction between the generalised use of human rights' protection within EU migration policy and the production of deaths at borders. Through an analysis of the EU's migration policy, this article suggests using Esposito's concept of immunitas to bridge inherent contradictions. Protection of life and the production of death are constitutive mechanisms of Western modern politics. This argument implies that human rights and the protection of life metaphorically legitimise the EU's control of migration from third countries, while blurring the underpinning logics of government, coloniality and racism. The article concludes that protection and the negation of (certain) lives are intrinsic to the EU's migration policy.
\end{abstract}

Keywords: Italian theory, immunitas, human rights, EU, migration policy, biopolitics, externalisation

Summary: 1. IntRoduction. 2. Biopolitics AND IMMUNITAS. ITALIAN THEORY APPLIED TO THE STUDY OF MigRATION. 2.1 MIGRATION POLICY AS AN IMMUNITY MECHANISM: THE PROTECTION OF LIFE AS THE MAIN CRITERION FOR THE LEGITIMATION OF POWER. 3. HUMAN RIGHTS AND EU'S MIGRATION POLICY: THE SEED FOR IMMUNITY. 3.1. THE PROTECTION OF LIFE and PRODUCtion of DEATH as CONSTITUTIVE ELEMENTS OF the EU'S MigRation POLICY. 4. The EU'S Regional Protection Programmes: an example of immunity. 5. Conclusions.

\section{INTRODUCTION}

Human rights' protection is the cornerstone of the European Union's (EU) identity and represents one of the main goals of its external action. Since the beginning of the integration process, the EU has progressively extended the promotion of human rights within Europe and in third countries. In 2009, the Treaty of Lisbon ${ }^{2}(E U, 2007)$ strengthened the EU's commitment to human rights' by placing their protection at the centre of the EU's external action (Gómez Isa, Churruca Muguruza \& Wouters, 2018, Churruca, 2019). Following the Joint Communication of the European Commission (EC) and the High Representative of the EU of the European Union for Foreign Affairs and Security Policy entitled 'Human rights and democracy at the heart of EU external action - Towards a more effective approach' (EC 2011), the EU Council (CoEU) adopted a strategic framework on human rights and democracy which shaped the EU's external action on human rights that affected all policy areas.

Migration issues have been included into the EU's external action (Commission of the European Communities, 2002) reinforcing the partnership with the countries of origin and transit as part of a process that has been called 'externalisation' (Lavenex, 2006; Lavenex and Wichmann 2009, Lavenex 2015; Lemberg-Pedersen, 2012; Moreno-lax and Lemberg-Pedersen, 2019). The council held in Tampere in 1999 (EU, 1999) established 
the Area of Freedom, Security and Justice (AFSJ), which made it necessary to control the EU's external borders and therefore to develop a common EU migration policy. In 2005 the European Commission adopted the Global Approach to Migration (CoEU 2005), which was modified by the Global Approach to Migration and Mobility (EC 2011b). These two policy documents, together with the European Agenda on Migration (EC 2015) and the new Pact for Migration and Asylum ${ }^{3}$ (EC 2020), furthered the inclusion of human rights' protection within the control of unwanted migration in non-EU countries (LembergPedersen, 2015; Moreno-Lax, 2020).

Despite the EU's protection framework and the fact that human rights have permeated migration policy, several NGO reports, migrants and activists have documented the increase of migrant human rights violations and deaths at EU borders. ${ }^{4}$ Detention centres, pushbacks, deportations, deaths, violence against migrants, shipwrecks, camps for stranded people and physical aggressions are daily occurrences. It therefore seems that the EU's migration policy has become progressively more violent and sophisticated, to the extent of affecting migrants' rights (Collyer, 2019). There is a strong inherent contradiction between the generalised use of human rights' protection and the simultaneous use of violence in terms of the 'strategic and systematic component' in EU migration politics and policies (Walters, 2011:150). As the use of violence produces migrants' deaths and human rights abuses, migration policies end up killing the very people that they claim to protect.

\footnotetext{
${ }^{3}$ The New Pact on Migration and Asylum was proposed the 23th September 2020 (EC, 2020). However, it is not agreed upon. The Pact does not represent any rupture in the continuity of the logic of the EU's migration policy; conversely, it intensifies its characteristics: accelerated procedures, externalization, return, increased securitisation, outsourced responsibility and shrinking asylum and solidarity space. I decided not to include it within this paper firstly, because the Pact was proposed while I was writing this article, and second, because it is still under construction. Contemporary negotiations on the New Pact are related to the opposition in some central elements of European southern countries. In particular, the 25th November 2020, Spain, Italy, Malta and Greece sent a letter to the European Commission stating that the Pact constitutes a good start but there is an imbalance in solidarity (RTVE 2020). Besides, in march 2021, Cyprus, Italy, Spain, Greece and Malta issued a joint declaration calling for the EU to guarantee the fair distribution of responsibility among Member States on migration, in which they 'stress the need for the future European Pact on Migration and Asylum to structure real and effective cooperation with the countries of origin and transit'. https://www.lamoncloa.gob.es/lang/en/gobierno/news/Paginas/2021/20210320athens-med5.aspx

${ }^{4}$ There is extensive academic literature on border studies. The understanding of borders has evolved from the late 1980s and early 1990s, when the analysis shifted from interpreting borders as territorial fixed lines dividing sovereignties to the idea of bordering as a set of socio-cultural and discursive processes and practices that are no longer solely the remit of political sciences and has become an interdisciplinary field of study. There was a transition from the concept of 'border' to that of 'bordering', which includes a critical reflection on the proliferation of border forms, functions and practices (Brambilla, 2015). After this shift from border to bordering practices, critical border studies were formalised as a distinctive approach in 2012, in response to the growing multiform complexity and disparity in the contemporary bordering practices which are both cognitive and separates 'us' from the 'others' (Parker \& Vaughan-Williams, 2012). According to Parker and Vaughan-Williams (2012), Critical Border Studies are a heterogeneous assemblage of thought on the nature and the location of the border. This approach problematises the border by putting it as a site of investigation, re-conceptualising it as a set of performances in multiple lived spaces where 'the border is not everywhere for everyone'. Lately, researchers have theorised a "processual turn" in border studies (Bambrilla, 2020) For the purposes of this paper, I will conceptualise 'borders' from a Critical Border Studies perspective, understanding borders as ubiquitous, multiple and dynamic.
} 
This radical biopolitical contradiction is a fundamental feature of contemporary European migration policies (Vaughan-Williams, 2017b, Foucault, 2006, Esposito, 2006, Esposito, 2005). Externalisation plays an important role in transferring the biopolitical contradiction into third countries between the stated goal (the protection of life) and its actual consequences (the production deaths of third-country nationals'-others-) (LembergPedersen, 2015). This modern contradiction has successfully penetrated external migration politics and policies, turning migrants into both threats and subjects of protection, who must be both simultaneously controlled and (theoretically) protected (Moreno-lax \& LembergPedersen, 2019). The EU's Regional Protection Programmes (RPP) are a paradigmatic example of the use of human rights' protection as a goal that legitimises covert repressive measures in third countries.

This article addresses the problematic relationship between the generalised use of human rights' protection in the external dimension of the EU's migration policy, and the violations of migrants' human rights and production of deaths of others at EU borders. It relies on a bio-political paradigm typical of Italian theory ${ }^{5}$, which particularly looks at migration policy as the place of re-production of a bio-political tendency of protection of life, while at the same time causing death (Campa, 2015). Despite Esposito's highly valuable ideas within migration studies, only a few works have applied his ideas to the analysis of migration policies. As an exception, Vaughan-Williams' analysis on human rights' protection has used Esposito's concepts, which I believe are fundamental to understanding the logic of EU migration policies.

This paper suggests that Esposito's concept of 'immunitas' is a useful context in the study of migration policies because it provides an opportunity to bridge the contradiction between human rights protection of life and the production of death inherent to EU migration policies. Immunitas allows us to overcome the duality born from Foucauldian biopolitical analysis present in contemporary migration studies. This duality, does not allow us to completely understand the nature of the contradiction within EU migration policies. However, the concept of immunitas serves to understand the protection of life and the production of death as constitutive elements of modern Western politics, where the negation of life is the logical consequence of the protection of life ${ }^{6}$ (Esposito, 2005). With immunitas, Esposito is answering the following question: why does a politics of life tend to reverse into a politics of death? The answer of Esposito's is that the reverse of politics of life is the death of others and those deaths serve to preserve the own political body (Esposito, 2012). This means that there is an intrinsic immunitarian logic in modern politics that serves to preserve and protect the (own) community. Esposito argues that, 'politics is nothing other than the possibility or the instrument for keeping life alive' (Esposito, 2008, p.46)). But at the same time, politics are not dealing with the preservation

\footnotetext{
${ }^{5}$ I would like to deeply thank Leopoldo A. Moscoso and Gerardo Costabile Nicoletta who brought these authors to my attention and helped me to understand them and feel them. I would like to acknowledge, specially, their help, patience, love, time and guidelines which were extremely useful for me not only professionally but personally.

${ }^{6}$ Esposito takes the example of the genocide in Germany during the Nazi the immunitary principle - already elaborated in his previous works, Communitas and Immunitas - is taken as the fundamental explanatory paradigm of modernity and of the deadly Nazi machine.
} 
of each single life, but with the power to protect the own political body. The immunitarian principle serves to simultaneously read positive power to affirm and preserve (certain) life and the negative power to negate and annihilate (others) life in order to protect the own body (the EU).

This argument is radical, because it implies that migrants' deaths are not only a negative consequence of controlling migration, but an inherent characteristic of modern migration management systems. In addition, immunitas serves to understand firstly, the EU's assumption that it does not have any obligations towards others (outside the community); secondly, human rights' protection as a mechanism of reinforcement of power and for the legitimation of migrants' repression (as an immunitarian principle typical of western politics); and thirdly, a European metaphor of self-perception that blurs the underpinning logics of governance, coloniality and racism under an immunitarian principle of protection.

This paper will first (1) outline the implications of using a bio-political paradigm for studying migration to illustrate the ideas of the so-called Italian theory. Second (2), it will exemplify Roberto Esposito's concept of immunitas in relation to migration. Third (3), it will analyse the three main EU migration policy documents, namely, the Global Approach to Migration (EC 2005), the Global Approach to Migration and Mobility (EC 2011) and the European Agenda on Migration (EC 2015) in order to show the inherent contradiction found in the EU's migration policy between the protection of life and the production of death. Fourth (4), it will describe the Regional Development and Protection Programme (RDPP) as a paradigmatic example of European immunity by focusing on the use of human rights' as a legitimising element of repressive measures in third countries. Finally, the paper will draw some conclusions.

\section{BiOPOLITICS AND IMMUNitas. ITALIAN THEORY APPLIED TO THE STUDY OF MIGRATION.}

Critical approaches to migration have placed the contradiction between the protection of life and production of death at the centre of academic biopolitical debates on migration. The biopolitical paradigm considers that there is an antagonistic dichotomy between the protection of life and production of death as a constitutive element of western modern politics (Foucault, 2006). This duality has a significant presence in migration politics and policies, which combine human rights' protection with coercive and repressive measures as a way of managing international migration. Migration politics are usually understood through a dichotomy where policies have the potential to both protect life and contain migration, but problematise explaining the relationship between them. A new approach that can integrate both aims is needed that will bridge the gap between policies (protection) and reality (production of death and violation of rights).

The biopolitical paradigm focuses on the relation between governance and population; between people and sovereign power. This paper relies on the so-called Italian theory that re-thinks Foucauldian biopolitics by producing useful concepts to critically 
approach the study of migration and borders. Italian theory constitutes one of the most successful approaches for a radical analysis of contemporary migration policies. Giorgio Agamben, Toni Negri and Roberto Esposito are key authors in a school of thought that is characterised by an obsession with disentangling the embryonic biopolitical opposition in modern politics between the protection of life and the production of death (Hardt, Negri, 2009, Foucault, 2006, Esposito, 2006, Agamben, 2016, Agamben, 2019). This opposition is strongly featured in the EU's migration policy, where 'irregular' migrants are presented as being both a security threat and threatened lives in need of saving (Vaughan-Williams, 2017b:95). Migration policies and politics have turned borders into complex spaces featured by both, protection of life and production of death. In this context, the biopolitical paradigm is particularly useful for the theoretical understanding of contemporary borders.

Biopolitics, as stated by Michel Foucault, serves to resume the modern transition from the right of sovereignty 'to take life or let live' to the right 'to make life and to let die'. After Foucault, Giorgio Agamben slightly corrected this argument by stating that the relationship between bios (political life) and zoè (the pure biological fact of living) is not only a modern constitutive feature of western politics but it has also been present in the political sphere to different degrees throughout history. Nonetheless, biopolitics entails an embryonic duality in contemporary politics: the protection of life and the production of death. These two sides have produced two different theoretical understandings. The first is a positive and vitalist drift and the second one is a negative one that prioritises the production of death, known as 'thanatopolitics' (Agamben, 2016) and later, 'necropolitics' (Mbembe, 2011).

When this dichotomy is transferred to the study of migration, 'letting die' means the production of death by failing to act. For example, exposing migrants to potential death; allowing boats to sink; neglecting their health care needs; blocking boats at sea; deportations; pushbacks; refoulements; leaving migrants stranded on Greek islands to the extent that they become desperate and commit suicide; and not assisting births in the forests of northern Morocco, to mention a few. On the contrary, making life has to do with human rights and the EU's proposals to protect people in need, the generalised categories of protection, different humanitarian NGOs working at sea and borders, refuge and asylum, among others ${ }^{7}$. Thus, the biopolitical paradigm unifies both possibilities because

\footnotetext{
${ }^{7}$ Critical humanitarian studies have addressed how this 'making life' appears to be in permanent opposition to 'making death', or 'humanitarian violence'. They have studied how 'humanitarian interventions could be seen as having replaced just wars' from a biopolitical perspective (Fassin \& Pandolfi, 2010:13). These studies have focused mainly on how humanitarianism and military interventions are legitimised through the protection of life but produce the 'least of the evils' (some deaths). Humanitarianism, is approached as an element connected with the protection of life and the production of death, with care and control (Weyzman, 2017:51). Some researchers have looked at the emergence of humanitarian government and to the inclusion of a 'humanitarian reason' in the governance of migration, borders and refugee camps (Agier, 2011:183, Fassin, Dieder, 2016). In order to understand global governmentality, this group of researchers have included in their analysis several biopolitical concepts such as 'bare life', 'inclusive exception' or 'life under a ban' which are typical within the Italian theory. This means that humanitarian studies and Italian theory are connected through biopolitics and its terminology and concepts. In this regard, border controls, refugee
} 
they are two sides of the same logic, which, according to this approach, is one of the main characteristics of modernity. Both sides, bios and thanatos are the two possible facets of the same logic.

This dichotomy takes centre stage in the contemporary study of migration policies from a biopolitical perspective. A specific group of theorists have attached more weight to the positive reading of biopolitics (Papadopoulos, Stephenson \& Tsianos, 2008, Hardt, Negri, 2009, Mezzadra, 2005, Mezzadra, Neilson, 2017), arguing that the power of bios is not reducible or governable; life is more powerful than darkness, and resistance is possible. These theories are usually referred to as the Autonomy of Migration (AoM) and are mostly linked to the well-known Italian thinker Toni Negri. They prioritise migrants' agency, subjectivity and the capacity of political contestation and resistance even inside detention centres and refugee camps. This positive reading is a reinterpretation of mobility 'as ontologically prior to any attempts by border security authorities' (Vaughan-Williams, 2017a:8).

In contrast, the negative face of biopolitics is to be found mostly in Agamben's idea of 'bare life' and 'exception' giving primacy to power over life (2016, Agamben, 2019). Agamben's interpretation of power is totalising, and this renders resistance and contestation problematic. Within a negative interpretation of migration policy focused on 'thanatopolitics' ${ }^{8}$, migration policies operate as a dehumanising element, exposing migrants to 'irregular status' and to lethal conditions. Refugee camps, detention centres and spaces of exception are at the core of the analysis. These negative and positive developments of biopolitics produce different poles how migration politics and policies is understood. However, neither can escape from the totalising dual argument and fail to provide a clear perspective on borders and migration. Thanatos and bios, life and death cannot read nuances and therefore they do not serve to understand the simultaneous relationship between protection and production of death at borders today.

Agamben and Negri's biopolitical analysis have been highly useful for a critical understanding of contemporary migration policies and politics. However, it is still necessary to go further into the theoretical analysis in order to include the simultaneous existence of both protection of life and production of death at borders. Border politics generate simultaneous mechanisms of protection and death production. In the following section, I will expose why Esposito's concept of immunitas is useful for the critical

camps, asylum process centres are interpreted as spaces of simultaneous control and care in relation with the humanitarian action (Ticktin, 2011, Fassin, Didier, 2012, Calhoum, 2013, Weyzman, 2017). Following this line, William Walters (Walters, 2011) put together security studies, humanitarian studies and border studies theorising the emergence of the "humanitarian border". Academic production on this topic has led to the development of critical biopolitical approaches to the study of borders and its technologies (Cuttitta, 2019, Cuttitta, 2018, Pallister-Wilkins, 2015, VAUGHAN-WILLIAMS, 2009). All those approaches rely on a biopolitical paradigm including biopolitical concepts as developed by the Italian theory. Despite the fact that academic production relies on Italian theory few take into consideration the potentialities coming from the concepts of Esposito's, particularly immunitas, when applied to migration studies, protection and human rights (Esposito, 2005).

${ }^{8}$ Further developed by Achille Mbembe as 'necropolitics' from a decolonial perspective (Mbembe, 2011) 
analysis of this dichotomy in order to provide a theoretical foundation for the following sections.

\subsection{Migration policy as an immunity mechanism: the protection of life as the main criterion for the legitimation of power}

Esposito's concept of immunitas is essential to understand the problematic relationship between the generalised use of human rights' protection within EU's migration policies and the violations of migrants' human rights and production of deaths at EU borders. The idea of immunitas is complex, but it is fundamental to an understanding of contemporary Western politics on migration. It assumes that the biopolitical contradictions typically inherent in modernity have permeated the political language of modernity, including borders and migration policies and politics (Esposito, 2005). In what follows, I will discuss the notion of 'immunity' and outline its theoretical implications in the analysis of migration policies.

It is essential to understand immunitas in relation to the concepts of communitas and 'biopolitics'. In order to understand Esposito's paradigm, ${ }^{9}$ it is important to recall Foucault's argument that an embryonic contradiction between the politics of life and the politics of death has inevitably emerged in human political history. In order to overcome this dichotomy, Esposito presented the concept of immunitas (2005), which represents a theoretical solution to the Foucauldian duality between bio-politics and thanato-politics. Esposito argues that Foucault was not completely right when pointing at biopolitics as a characteristic of modern politics; in his view, it is not biopolitics that characterises modernity but immunitas. Biopolitics, according to Esposito, has existed since ancient times; however, it is immunitarian principle that constitutes a fundamental element of modernity. Immunitas is, firstly, an intrinsic mechanism of reproduction of the political body and therefore of the community; and secondly, immunitas is located at a crossroads between law-rights (legal dimension) and life-bios (biological dimension), drafting two lines of meaning, one juridical and one related to the semantics of biology. Immunity has to do with the attempt to protect life and relying on political categories that tend to turn against themselves.

Regarding the juridical meaning, Esposito goes back to the legal notion of the ancient Greek. In im-munitas, the prefix 'im' is the negation of munus. Munus is the duty to give to others, the obligation to prioritise the necessity of others, a gift that must be restored to the community. The idea of munus shatters individuality, while shaping communality. Munus is the 'absence' that we have in common with the members of the community, it is what constitutes 'us' and makes us part of the community. By using munus, Esposito moves away from the concept of membership through possession and transforms it into membership through absence. Im-munitas is the absence of an obligation towards 'others'; someone who is immune has no obligation towards others and is exempt

\footnotetext{
9 These ideas are developed in the three books by Roberto Esposito: Bios. Biopolitics and philosophy, Communitas. Origin and destiny of the community (2006) and Immunitas (2005) The protection and negation of life.
} 
from any obligations to the community. The negation of munus represents a rupture of communal exchange; it disrupts the social community circuit. If we interpret the EU's migration policy as an immunity mechanism, the assumption would be that EU institutions consider that they have no obligation to the 'migrant others', because they do not consider those specific migrants to be part of our community, of the own body. The EU has no obligations towards them because they are not 'us'; they are a threat to 'our' community.

As far as the biological dimension of immunity is concerned, it has to do with the idea of gaining protection from danger. Immunity is a simultaneous relationship between the protection and the negation of life, which is in a fragile equilibrium. A body needs to gain immunity from dangerous external elements such as illness and invasions that pose a threat to the reproduction of the community, to the survival of the (political) body. Furthermore, illness needs a living body in order to survive, for if the body dies, illness cannot survive, and the reproduction of life becomes impossible. If a community is in danger, it is necessary to develop immunity responses to protect the community-body, to absorb the invasion in order for life to prevail. Politics aims to protect the life of the community and in order to do that, dangers must be neutralised by gaining immunity. The protection of life is the most powerful legitimation of the production of death, it excludes through inclusion. The protection of life functions as the inclusive immunitarian element that serves to legitimise power and the production of certain deaths (Esposito, 2005).

Within this medical metaphor game, it may be easy to envisage healing a body by using the same poison (or virus) that caused the disease: a vaccine or pharmakon. Vaccines are made using the same components that are found in a disease; they are inoculated into the body in non-lethal quantity to provoke immunity. However, if the amount is excessive, the body will die. Immunity generates resistance to the external elements that had invaded the community-body, including the illness to the whole. In this regard, the body is victorious when it succeeds in incorporating the poison into itself; the body does not eliminate the poison, it neutralises and includes it into the whole. In the words of Esposito $(2005,2006)$, nothing reinforces the host body better than an illness that has been dominated and turned against itself. If we interpret EU migration policy as an environment for the reproduction of the immunity mechanism, we can recognise that migration is socially constructed as an external threat to the body-community. In order to be neutralised, the illness/threat must be combated by incorporating it in exactly the same way as viruses or bacteria are into vaccines.

The EU's immunity mechanisms counteract the perceived threat by including migrants/illness through exclusion. In other words, the EU uses the same political categories that keep the body alive, protecting life to neutralise dangers like a vaccine reproduces life through an antidote. The protection of life legitimises repression, death and power. Fighting illness will always legitimise repressive responses by constructing an external enemy (Esposito, 2005, p. 176). In this respect, the opposition between the generalisation of human rights and increase of migrants' deaths is an example of the immunity mechanisms that neutralise the enemy by incorporating it into the political body. The protection of life, of human rights against the external enemy, serve to protect the community from the threat/victim/migrant/other. Migration control policies and human 
rights are part of an immunity reaction that involves the same violence it intends to neutralise, where the protection of life, particularly as it is materialised in human rights, is the main criterion for the legitimation of power (Esposito, 2005). Immunity is an account of itself, a metaphoric narrative of the self, which gives meaning to the modern order while concealing the underpinning structures of power.

\section{HUMAN RIGHTS AND EU'S MigRATION POLICY: THE SEED FOR IMMUNITY.}

In 2002, the UNHCR's Global Consultation on International Protection involved States, including the EU Member States, in the Agenda for Protection. This agenda was intended to develop 'special' or 'multilateral' agreements to ensure improved burden sharing, with countries in the North and South working together to find durable solutions for refugees. This included 'comprehensive plans of action to deal with mass outflows, and agreements on "secondary movements", whereby the roles and responsibilities of the countries of origin, transit, and potential destination are better defined' (UNHCR, 2002: 6). The UNHCR Programme of Action called on States 'to examine the root causes of refugee movements, particularly armed conflict, and to devote greater resources, both human and financial, in developing respect for human rights' (UNHCR, 2002: 11). The EU internalised this international generalisation of protection as a means of migration management

The EU had already placed human rights' protection at the cornerstone of its external action within the Treaty of Maastricht ${ }^{10}$ (TEU) (EU, 1992). Article J-1 of Title V, Provisions on a Common Foreign and Security Policy, established that one of the objectives of the common foreign and security policy was to "consolidate democracy and the rule of law, and respect for human rights and fundamental freedoms'. In addition, Article 21 $\mathrm{TEU}^{11}$ provides that 'the Union shall seek to develop relations and build partnerships with third countries' pursuing 'democracy, the rule of law, the universality and indivisibility of human rights and fundamental freedoms, respect for human dignity, the principles of equality and solidarity, and respect for the principles of the United Nations Charter and international law' (EU, 2012). The EU's protection framework for the external action culminated with the Treaty of Lisbon in 2009, which made human rights a must in its relationships with third countries.

The protection of human rights is a key element to the construction of the Area of Freedom Security, and Justice (AFSJ) established in the EU Council held in Tampere (EU, 1999). The construction of the AFSJ strengthened the incorporation of migration issues into foreign policies, connecting internal and external action. At that point, the Union needed to 'develop common policies on asylum and immigration while taking into account a consistent control of external borders to stop illegal immigration and to combat those who organize it and commit related international crimes' (EU, 1999, paragraph 3). Following an immunitarian logic, the idea of controlling who comes from outside in order to protect the inside (the community) is the backbone of EU migration control beyond borders. In this equation, partnership between Member States and third countries

\footnotetext{
${ }^{10}$ Entered into forced 1 November 1993

${ }^{11}$ In its consolidated version of 2012
} 
is fundamental to govern migration. Thus, the EU seeks to combine policies targeting poverty and conflict prevention and to strengthen democratic states by ensuring respect for human rights (EU, 1999, paragraph 11). The Union is 'fully committed to the obligations of the Geneva Refugee Convention and other relevant human rights instruments, able to respond to humanitarian needs on the basis of solidarity', and this requires offering 'guarantees to those who seek protection' (EU, 1999, paragraph 3 and 4). In this way, third countries might contribute to preventing people from migrating to the EU; this would help the EU to contain threats coming from outside. This process blurs the threshold between 'in and out', while transferring European interests onto non-EU countries by following colonial logics.

In 2002, the conclusions from the Seville European Council reinforced the external dimension of migration policy through cooperation 'with the countries of origin and transit' (Council of the EU, 2002, paragraph 27). The Council emphasised that protection should be included in its external relations with third countries on migration issues, thus intensifying the 'root causes approach' (Balzaq, 2008). One year later, the Thessaloniki European Council (CoEU, 2003) reaffirmed the combination of human rights' protection, external action and migration control. In particular, the Presidency Conclusions highlighted the importance of participation in the relevant international human rights instruments, ${ }^{12}$ while reiterating the need for cooperation with non-European countries in managing migration and in the creation of asylum systems, with specific reference being made to access to effective protection. The European Parliament resolution on asylum procedure and protection in regions of origin invited the Commission to 'examine ways and means to enhance the protection capacity in regions of origin with a view to presenting to the Council, before June 2004, a comprehensive report suggesting measures to be taken, including legal implications' (European Parliament, 2005, p. 228). The Thessaloniki Council put on the table the idea of 'delivering protection' to third countries as a way of governing migration, following the line of the UNHCR Agenda for Protection (UNHCR, 2002).

\subsection{The protection of life and production of death as constitutive elements of the EU's migration policy}

Three main policy documents form the basis for the structure of the EU's migration policy: The Global Approach to Migration (GAM) in 2005, the Global Approach to Migration and Mobility (EC, 2011b) and the European Agenda on Migration (EC, 2015). All three were launched after a violent and depoliticised event that was aimed to 'respond to the challenges of migration' (CoEU, 2005, p. 3) and to create strategic 'strong links and alignment between relevant EU policy areas and between the external and internal dimensions of those policies' (EC 2011b, p. 3). The EU's migration policy has been 'reactive' over time; this means that policy documents are generally produced as an institutional reaction to dramatic events such as shipwrecks, murders, mass arrivals, wounded migrants, tortures or migrants' deaths. These events serve as 'accelerating pills'

\footnotetext{
${ }^{12}$ Conclusion 19 from Thessaloniki mentioned Conventions on Human Rights, including the Geneva Convention of 28 July 1951 relating to the status of refugees as amended by the New York Protocol of 31 January 1967, among others.
} 
for the EU's political action in shaping public opinion (Castles, 2004). In this sense, life and death appear indubitably entwined in immunity terms within the process of EU migration policy construction.

The external dimension of EU migration policy has been characterised by the generalised introduction of human rights' protection over time. However, an intrinsic contradiction stems from the violation of migrants' rights and the production of death at the EU's borders. There is a seamless link between the how EU migration policy has fared in terms of protection over time and the production of death at EU borders. In 1988, the Spanish newspaper El País (Narvaez, 1988) published an account of the first death in the western Mediterranean. It was about a Moroccan migrant and eighteen other people who had disappeared while attempting to reach the Spanish coast. One year later, the first fences were built between the North African Spanish towns of Ceuta and Melilla and Moroccan territory. The erection of the fences provoked incidents in the Moroccan neighbouring areas, and in 2005 at least five people were killed by direct shots (Abad and Rodriguez, 2005) as they attempted to enter Ceuta. Responsibility for this has still not been allocated either by the Spanish or the Moroccan authorities (Medicins sans Frontiers, 2005). In parallel, the situation in Lampedusa in the central Mediterranean route was also a matter of concern for both the European Parliament (2005b) and for the UNHCR (2005). The high number of arrivals, together with the living conditions at the local facilities and the collective expulsions to Libya, were clearly in violation of migrants' rights at the time. As a reaction of those events, the Commission launched the $\mathrm{GAM}^{13}$ in December 2005, targeting the European Mediterranean region.

The GAM mentioned the need to 'help' third countries to 'meet their obligations under the 1951 Geneva Convention and other relevant international instruments on international protection, fighting illegal migration, trafficking in human beings' (CoEU, 2005). In this way, migrant human rights' protection was presented to be part of a European goal to be achieved by third countries with the 'help' of the EU. The Union would contribute to the 'capacity building' of those other countries of origin and transit that were not able to protect migrants and asylum seekers by themselves. 'The EU will strengthen its dialogue and cooperation with all those countries on migration issues, including return management, in a spirit of partnership and having regard to the circumstances of each country concerned' (CoEU, 2005, p. 3). Through the GAM, the European Council recognised the importance of tackling the root causes and human rights as part of a 'long-term process to respond to the opportunities and challenges of migration'. The GAM specifically mentioned, 'the creation of livelihood opportunities and the eradication of poverty in countries and regions of origin, the opening of markets and promotion of economic growth, good governance and the protection of human rights'

\footnotetext{
${ }^{13}$ A Global Approach to Migration was adopted by the European Council in 2005 and confirmed by the 2006 Council. 'The Global Approach aims to formulate comprehensive and coherent policies that address the broad range of migration-related issues, bringing together different policy areas'. 'The Global Approach has a strong theme of working in partnership with countries of origin and transit: its key concepts are partnership, solidarity and shared responsibility' MEMO/07/549 Brussels, 5 December 2007, Global Approach to Migration. https://ec.europa.eu/commission/presscorner/detail/en/MEMO_07_549
} 
(CoEU, 2005, p. 3). In this way, the GAM reinforced the incorporation of protection into the EU external action regarding migration in the Mediterranean region.

While the GAM constantly referred to human rights' protection and capacity building in third countries, migrant deaths occurred at EU borders. After the release of the GAM, more than 31,678 people arrived in the Canary Islands in 515 dinghies $^{14}$ (generally known as pateras or cayucos in Spanish), and around 6,000 died in the attempt during the so-called 'cayucos crisis' in $2006^{15}$ (International Peace Institute 2016). The immunity contradiction stems from a radical dichotomy: protection of human rights was simultaneous to the production of death at EU borders. The development of EU's migration policies over time has gone hand in hand with both the introduction of protection in foreign policy and the use of violent practices at EU borders. In 2008 the European Directive on Return often referred to as the Returns Directives (CoEU, 2008) was adopted, which allowed for the deportation and detention of migrants in specific centres to become established in all EU Member States. Deaths and violations of rights were also reproduced within internal borders. In 2007, Osamuyi Akpitaye was suffocated to death during the assisted deportation flight from Spain to Nigeria, after his guards duct-taped his mouth (Duva, 2007). As a result of the same repressive and violent logic, Samba Martín ${ }^{16}$ died in 2011 while detained in the Madrid detention centre in Aluche with no medical assistance. Alik Manukyan (Rodriguez, 2013) and Idrissa Diallo (European Parliament, 2012) died in the Zona Franca migrants' detention centre in Barcelona in unclear circumstances.

In parallel, the extension of protection continued with the creation of the European Asylum Support Office (EASO) in 2010. The EASO was created in order to 'help Member States fulfil their European and international obligations to give protection to people in need' (EU, 2010). One year later, in 2011 FRONTEX extended its agency's mandate ${ }^{17}$ while simultaneously introducing obligations related to fundamental rights (Meissner, 2017). The Union consolidated the expansion of human rights' protection onto migration policy, multiplying both internal and external borders and spreading the violation of migrant rights and migrant deaths (Orgaz Alonso, 2018, p. 238)

\footnotetext{
${ }^{14}$ Small boats.

15 'Cayucos' refers to the fisher wooden boats typical from Senegal that were used to travers from Senegal to Canary Islands during 2005 and 2006. In 2005, 4,718 people reached the Canary Islands, in 2006 the number jumped to 31,859 . Almost half $(16,237)$ came from Senegal, while other major countries of origin included Gambia (3,633), Morocco (3,423), Côte d'Ivoire (1,698), Guinea-Bissau $(1,448)$, and Mauritania $(1,237)$ (International Peace Institute 2016).

${ }^{16}$ Only in November 2020 (almost 10 years later) did Spain recognise its responsibility in Samba's death. https://www.elsaltodiario.com/cie/el-estado-espanol-admite-su-responsabilidad-en-la-muerte-de-sambamartine

${ }^{17}$ Regulation (EU) No 1168/2011 of the European Parliament and of the Council of 25 October 2011 amending Council Regulation (EC) No 2007/2004 establishing a European Agency for the Management of Operational Cooperation at the External Borders of the Member States of the European Union. The pint number 9 establishes that 'The mandate of the Agency should therefore be revised in order to strengthen in particular its operational capabilities while ensuring that all measures taken are proportionate to the objectives pursued, are effective and fully respect fundamental rights and the rights of refugees and asylum seekers, including in particular the prohibition of refoulement'. See: https://eur-lex.europa.eu/legal-content/ EN/TXT/PDF/?uri=CELEX:32011R1168\&from=EN
} 
The Arab Springs and the beginning of the war in Syria caused thousands of displaced people to arrive at European borders seeking refuge. Again, the EU reacted by releasing another policy document known as the GAMM (EC, 2011b), which elevated migrants' human rights protection. The new GAMM (EC, 2011b) served to update the 2005 GAM to the new migration situation ${ }^{18}$ of displacement and border crossing provoked by the Arab Springs in the Mediterranean region. With the new approach to migration, human rights' protection gained a central role. The provisions referred to the need for a 'more strategic and more efficient, with stronger links and alignment between relevant EU policy areas and between the external and internal dimensions of those policies' (EU, 2011 b, p. 3). Having placed the protection of migrants' rights at the very core of the policy, the GAMM was structured around four thematic priorities crosscut by human rights: (1) legal migration and mobility; (2) the fight against irregular migration; (3) the promotion of international protection and the enhancement of the external dimension of asylum policy; and (4) the migration-development nexus (EC, 2011b).

Again, the GAMM extended available protection through the inclusion of human rights in the strategy towards third countries, and by multiplying the categories eligible for protection. The GAMM protected not only refugees and asylum seekers, but also other vulnerable groups such as displaced victims and vulnerable migrants, including nonaccompanied children, stranded migrants, forced displaced people, victims of trafficking or migrants, regardless of their legal status (Zetter 2014). However, more than 1,500 people drowned or went missing while attempting to cross the Mediterranean that year. The year 2011 was one of the deadliest years for the Mediterranean region until then, according to the UNHCR. The GAMM exemplified how human rights' protection could be extended to other categories, and showed how the modern immunity language of the protection of life and production of death permeates the EU's migration policy.

The GAMM included as the transversal role of human rights in foreign policy, specifying that 'the dialogue and cooperation with partners should strive to protect the human rights of all migrants throughout their migration process'.

'The human rights of migrants are a cross-cutting dimension, of relevance to all four pillars in the GAMM. Special attention should be paid to protecting and empowering vulnerable migrants, such as unaccompanied minors, asylum-seekers, stateless persons and victims of trafficking. This is also often a priority for migrant source countries. Respect for the Charter of Fundamental Rights of the EU is a key component of EU policies on migration. The impact on fundamental rights of initiatives taken in the context of the GAMM must be thoroughly assessed'.

$$
\text { (EC, 2011b, p. 16). }
$$

Potential actions targeting migration issues at the place of origin and during transit should include elements of prevention and prosecution of 'human rights violations

\footnotetext{
${ }^{18}$ See the UNHCR's update of June 2011 as an example of the numbers of displaced people in as a consequence of the Arab Spring: https://www.unhcr.org/4df9cde49.html
} 
committed against migrants' and 'measures should be taken to ensure decent living conditions for migrants in reception centres and to avoid arbitrary or indefinite detention' (EU, 2011, p. 16). Despite the continuous references made in GAMM to human rights' protection, political turmoil and violence within North African countries during and after the Arab Springs severely increased human rights violations and migrants' deaths at EU borders. Since early 2013, the Egyptian police have reportedly detained more than 6,800 persons fleeing Syria (Kingsley, 2014) and it was reported that 'Egyptian soldiers fired on smuggling vessels heading for Europe ... packed with Palestinians fleeing the destruction in Gaza wrought by Israeli bombing' (Grange, Flynn, 2014). Lastly, in February 2014 at least 14 people died after the Spanish Guardia Civil shot tear gas at migrants in the water as they attempted to reach Ceuta by sea. One disappeared, and 23 were refouled to Morocco without any legal procedures being followed. ${ }^{19}$ Again, no one was held responsible, and death was present at EU borders.

In 2015, a shipwreck in which at least 800 people died only $110 \mathrm{~km}$ away from the Italian coasts (The Guardian, 2015) was presented again as an inevitable tragedy void of any political responsibility. EU institutions again portrayed themselves as being responsible for the protection of those migrants who risked their lives in the Mediterranean. The European Council released a special statement on 23 April 2015 aimed at preventing the loss of lives at sea and to tackle the root causes of the human emergency in cooperation with the countries of origin and transit. ${ }^{20}$ The commission issued the European Agenda on Migration (EC, 2015) which provided that the immediate imperative was 'the duty to protect those in need'. A significant section of the document was devoted to 'Europe's duty to protect'.

The European Agenda on Migration identified 'four pillars to manage migration better', gearing efforts across the four pillars towards containing unauthorised movement, reinforcing return and readmission, enhancing border controls and 'support[ing] third countries to develop their own solutions to better manage their borders'. Among the immediate measures to be taken was developing a common approach for granting protection to displaced persons in need of protection (EC, 2015, p. 4). ${ }^{21}$ The EU clearly has a duty to contribute to help 'displaced persons in clear need of international protection' always 'working in partnership with third countries to tackle migration upstream' (EC, 2015, p. 4).

Despite the general references to and frameworks for human rights' protection, different NGOs and international bodies have provided evidence of the violation of migrants' rights at EU borders. Human rights violations are not only committed on land but also at sea through blocking practices by authorities that cause deaths, pushbacks, or

\footnotetext{
${ }^{19}$ See CEAR, Caso Tarajal https://www.cear.es/caso-tarajal/

${ }^{20}$ Special meeting of the European Council, 23 April 2015 - statement https://www.consilium.europa.eu/en/ press/press-releases/2015/04/23/special-euco-statement/

${ }^{21}$ Categorisation for those that are not in need also involves measures to manage migration. For "those not in need of protection', the EAM pointed to Frontex to help Member States by coordinating the return of irregular migrants' (EU, 2015, p. 6).
} 
the denial of access to land. Specifically, in 2017 Human Rights Watch reported violation of migrants' rights and pointed at the need for collaboration with Morocco (Human Rights Watch, 2014, 2016). Refoulements of black migrants at the southern Spanish border (CEAR, 2015, 2017) are a systematic practice that has been denounced by several local organisations and $\mathrm{NGOs},{ }^{22}$ as they pose a risk to life through forced displacement, abuses and illegal detentions and deportations (GADEM 2018, 2018b). Amnesty International (2018) also published reports referring to the 'cruel European migration policies' concerning the situation in Libya in 2018. In the same year, and also in Libya, Human rights Watch referred to EU policies as a 'contribution to the abuse of migrants' (Human rights Watch, 2019). Therefore, the incorporation of human rights' protection into external action, and the proliferation of protection categories and vulnerable groups have characterised EU migration policy developments in recent years. However, claiming to protect everyone everywhere can result in protecting nobody nowhere (Moreno-Lax, Lemberg-Pedersen, 2019).

Up to now, the contradiction between the proliferation of human rights protection and the production of migrants' deaths at borders has been identified as constitutive of EU's migration policies. In the following section, Regional Protection Programmes will be used to illustrate an example of how immunitas is present within EU's migration policy and how the protection of life serve legitimises the externalization of migration policies.

\section{The EU's Regional Protection Programmes: an example of IMMUNITY.}

Regional Protection Programmes are a paradigmatic example of the use of human rights' protection as a concealed aim to legitimise contention measures in third countries. Protection serves to legitimise intervention, which in terms of Esposito, follows an immunitarian logic. Protection beyond borders is presented as a way of migration management, based on the understanding that enhancing areas of protection will contain migration while at the same time protecting life. The protection of life might neutralise threats to the community. These programmes are examples of the metaphoric representation of the EU as a political body that needs to be protected and finds in human rights protection a legitimating element to keep itself safe.

As mentioned above, in 2000 the UNHCR instigated a round of Global Consultations on International Protection in order to 'engage States and other partners in a broad-ranging dialogue on refugee protection'. It aimed 'to explore how best to revitalise the existing international protection regime while ensuring its flexibility to address new problems' (UNHCR, 2002). The Global Consultation process among governments, intergovernmental and non-governmental organisations, and refugee experts gave place to the adoption of the 'Agenda for Protection' (UNHCR, 2002). The Agenda built on the Geneva Convention, which was reflected in the reference to a 'Convention Plus' approach. The 'Convention Plus' reinforced protection through durable solutions for

${ }^{22}$ See, for example, Iridia, Prodein, APDHA, Caminando Fronteras, CEAR on pushbacks, deportation, detention conditions, asylum access, abuse, discrimination. 
displaced people by implementing return, resettlement and voluntary repatriation or integration.

The UNHCR encouraged States to implement the Geneva Convention of Refugees in order to revitalise the protection framework worldwide, including in the EU Member States. In Europe, the Thessaloniki EU Council conclusions (2004) adhered to the ideas of the Agenda for Protection and specified the need to explore all possible ways of making the entry of people in need of protection 'orderly and managed'. The conclusions invited the Commission to "examine ways and means to enhance the protection capacity of regions of origin with a view to presenting to the Council, before June 2004, a comprehensive report suggesting measures to be taken, including legal implications':

'As part of this process, the European Council notes that a number of Member States plan to explore ways of providing better protection for the refugees in their region of origin, in conjunction with the UNHCR. This work will be carried out in full partnership with the countries concerned on the basis of recommendations from the UNHCR'

(CoEU 2003)

In November 2004 (CoEU, 2004) the Council encouraged 'the Commission to develop EU-Regional Protection Programmes in partnership with the third countries concerned and in close consultation and cooperation with the UNHCR'. Following this, in September 2005, the Commission defined Regional Protection Programmes (RPPs) (EC, 2005) in a communication specifically entitled 'Regional Protection Programmes', which would be included in the GAM in December 2005. These programmes were intended to 'be brought forward with the intention of enhancing the protection capacity of the regions involved and better protecting the refugee population there by providing durable solutions.

These programmes will incorporate a variety of relevant instruments, primarily focused on capacity building, and include a joint resettlement programme for those Member States which may be ready to participate in such a programme on a voluntary basis. With regard to countries of transit, the European Council emphasised the need for intensified cooperation and capacity building, both on the southern and eastern borders of the EU to enable those countries better to manage migration and to provide adequate protection for refugees.

(EC, 2005)

The Final Communication on RPPs (EC, 2005) stipulated two regional priorities for creating regions of protection: western newly independent states and the region of the Great Lakes in sub-Saharan Africa, while it defined other potential areas to be developed in the future such as North Africa, the horn of Africa and Afghanistan. Following this logic of human rights' protection, the GAM similarly encouraged the creation of Regional Protection Programmes (EC, 2005) in countries of transit and origin. The GAM called on international bodies such as the UNHCR to develop protection capacities in non-EU countries. 
'Regional Protection Programme should be situation specific and protection oriented. It should draw on a range of measures, such as assistance to third countries to comply with international obligations under the Geneva Convention and other relevant international instruments, to enhance protection capacity, better access to registration and local integration and assistance for improving the local infrastructure and migration management. The development and the implementation of these programmes should be taken forward in close cooperation with UNHCR and, where relevant, other international organisations. Possible EU and other funding sources should be indicated. Coherence with the Community approach towards the region and third countries concerned should be assured'

(EC, 2005b, paragraph 3)

In the same immunity logic of applying protection from threats that are trying to invade the body, the protection mechanism aims to find sources of risk in order to neutralise them. Measures are then justified and legitimised thorough the need to provide protection everywhere. The GAMM (EC, 2011b, p. 5) reiterated the importance of RPPs, by re-affirming the idea that 'the EU should increase cooperation with relevant non-EU countries in order to strengthen their asylum systems and national asylum legislation and to ensure compliance with international standards. Under its third pillar, entitled 'promoting international protection and enhancing the external dimension of asylum policy' (EC, 2011b, p. 17), the Member States consider that the EU should support third countries to ensure a 'higher standard of international protection for asylum-seekers and displaced people who remain in the region of origin of conflicts or persecution' (EC, 2011b, p. 17). The GAMM specifically mentioned that 'asylum policy frameworks and protection capacity in non-EU countries must be strengthened' and that 'this is to be achieved by means of more extensive cooperation with non-EU countries, inter alia, under Regional Protection Programmes'.

Relying on the a human rights-based approach adopted in previous RPPs, Regional Development and Protection Programmes (RDPP) added a stronger emphasis on development ${ }^{23}$ in order 'to better understand, plan, and mitigate the impact of the forced displacement of Syrian refugees on host communities'.${ }^{24}$ RDPPs are a multi-donor European initiative intrinsically linked to human rights' protection and specifically to the UNHCR's 'durable solutions' (voluntary repatriation, resettlement to third country, and local integration in country of asylum). They were progressively implemented in different regions and led by different Member States. In 2014, the RDPP for the Middle East was led by Denmark as a response to Syrian displacement and 'to ensure that refugees and host populations ... access their rights'. In 2015, the RDPPs for the North African (NA) region and the Horn of Africa were set up as an important part of the EAM. In 2016, the NA RDPP, led by the Italian Home Office Ministry and funded by the Asylum Migration and Integration Fund (AMIF), was established for the period 2016-2020, covering supporting activities in Algeria, Chad, Egypt, Libya, Mauritania, Morocco, Niger and

\footnotetext{
${ }^{23}$ For further information, see reports at https://rdpp-me.org/rdpp-reports

${ }^{24}$ Ibid.
} 
Tunisia on registration, refugee status determination, durable solutions, child protection, direct assistance activities, capacity building and awareness activities..$^{25}$ The RDPP for the Horn of Africa, ${ }^{26}$ was led by the Netherlands in order 'to improve protection and enhance development prospects of refugees, internally displaced people and local communities, aiming to offer an alternative to risks of irregular migration ${ }^{627}$ and funded by the EU trust Fund for Africa. With a view to provide long-term solutions, "their aim is to assist third countries to address the protection and developmental needs of migrants, refugees and asylum seekers, support the efforts of the migrant and refugee hosting communities, and build capacities of the authorities ' ${ }^{28}$

Together, RPPs and RDPPs are paradigmatic examples of the use of human rights' protection as a concealed aim to legitimise intervention on migration issues in third countries. They implement protection as a means of controlling migration, as an immunity mechanism for the prevention of migrant threats. Protection of different vulnerable groups, human rights and, in general, enhancing protection legitimises intervention in third countries. The protection of life is the stronger legitimation for any measure. Paradoxically, violence and therefore the production of death at EU borders is everyday more and more common. In addition, RDPPs show the metaphorical self-perception of the EU as a political body that needs to be protected from external threats, and believes that migration is an illness to be cured. Despite the generalised framework of human rights and the proliferation of categories of people in need of protection, there is no evidence of the effectiveness of the protection on migrants' rights, because protection schemes ultimately kill those it claims to protect, in the approach to life and death that is inherent to modern Western politics. RPP and RDPP serve as paradigmatic examples of how protection and human rights legitimate the intervention in migration issues in third countries.

\section{Conclusions}

Biopolitics follows in the wake of the modern transition from the right of sovereignty 'to take life or let live' to the right 'to make life and to let die'. A biopolitical paradigm brings this dichotomy to the centre of the analysis. Foucault's analysis of the relationship between life and politics focused on the intrinsic relationship between life, death and governance. According to Foucault, biopolitics is the main characteristic of modern politics. Italian philosophers like Giorgio Agamben, Toni Negri or Roberto Esposito have revisited biopolitics from different perspectives, giving place to the socalled Italian theory.

\footnotetext{
${ }^{25}$ RDPP NA Fact Sheet https://ec.europa.eu/home-affairs/sites/homeaffairs/files/docs/publications/bls193 46 factsheet_general.pdf

${ }^{26}$ It refers to Eritrea, Somalia and South Sudan.

27 RDPP for Horn of Africa https://www.khartoumprocess.net/operations/31-regional-developmentprotection-programme-rdpp-horn-of-africa

${ }^{28}$ This website was set up during conversations with the manager of the RDPP in North Africa. There was almost no public information about these programmes. In April 2020 the EC created this page to provide further information on Regional Development and Protection Programmes https:/ec.europa.eu/home-affairs/ news/20200427_regional-development-protection-programmes-north-africa-projects-implementation_en
} 
The Italian theory places the biopolitical contradiction at the core of theoretical discussions about migration. This results in two interpretations. A positive one relates to Toni Negri's work and privileges life and migrant agency over death. Researchers following Negri have established a specific way of thinking radically about migration and the Autonomy of Migration. The second interpretation gives priority to the totalising negative reading of Agamben, known as thanatopolitics. Neither of these schools of thought have succeeded in producing a consistent explanation of the relationship between the two consequences of approaching migration from a biopolitical paradigm.

Roberto Esposito coined the concept of immunitas as a theoretical solution to the dichotomy that articulated the two possible theoretical drifts of biopolitics. The concept of immunitas allows to radically look at borders and migration policies and attempts to bridge the gap between the two existing trends in migration studies. Esposito suggests that immunitas is the main constitutive element of modern Western politics - and not biopolitics - and presents the immunity-based negation of life as the logical consequence of the protection of life.

Despite the vast critical potential of Esposito's theoretical tenets, few researchers have applied his ideas to the study of human rights in migration as an immunity-based legitimising element and his theoretical links to the idea of communitas. Esposito's philosophy provides useful and radical tools for the interpretation of migration policies.

The biopolitical contradiction is embedded in the EU's migration policy and externalised in relationships to third countries. Despite the EU's protection framework and the constant presence of human rights elements within migration policy, migrant deaths occur daily at EU borders. This article aims to understand the relationship between the protection of life, incorporated into the EU's protection framework and specifically into migration policy, and the production of migrants' deaths at its borders.

Relying on Esposito's philosophy, and on the analysis of three main policy documents and some RDPPs, this article has suggested that this contradiction is not only possible but inherent to EU migration policy. It has also proposed the application of the concept of immunitas to the study of migration in order to approach the use of human rights' protection within EU migration policy (GAM; GAMM and EAM) as an element of the legitimation of power that serves to unlock liberal constraints to control migration in third countries. Esposito facilitates an approach to migration politics as an environment for the re-production of a biopolitical tendency of protecting life while delivering death to certain bodies.

This article has illustrated that the EU's generalisation of human rights' protection has exactly the opposite effect than it claims: the negation of (certain) lives. It highlighted the metaphorical self-understanding of Europe itself that serves to blur the underpinning logics of governance, coloniality and racism. Esposito allows us to look at the EU's assumption of a loss of obligations towards the 'others' as a mechanism that unveils a racist assumption that migrants do not belong to the community, but are a kind of 'disease' to be neutralised. Thus, using immunitas as a theoretical tool, serves to facilitate a radical 
understanding of the contradiction present in EU migration policies between the protection of life and the production of death and to highlight the fact that human rights' protection legitimises migrants' repression at EU borders and third countries, following colonial logics.

Finally, this article has shown that immunitas is a useful concept to look at migrant deaths as a consequence of an inherent characteristic in the relationship between life and politics in modern Western migration governance, which protects certain lives while bringing death to others. It has done so by using RPPs and RDPPs as paradigmatic examples of how human rights can be used to legitimise migration control in third countries within EU migration policy.

The radical potential of the Italian theory and, in particular, the concept of immunitas, is useful to understand contemporary migration politics. However, further theoretical research is needed in this area in order to analyse the role that coloniality, gender and race play in the production of death. Italian theory and the concept of immunitas are extremely valuable and should be applied to migration studies.

\section{REFERENCES}

ABAD, R. and RODRÍGUEZ, J. (2005). 'Cinco inmigrantes mueren tiroteados en Ceuta tras intentar saltar la valla 600 subsaharianos' El País, September 30th 2005 https://elpais.com/diario/2005/09/30/espana/1128031201_850215.html

AGAMBEN, G. (2016). El poder soberano y la nuda vida. Valencia: Pre-Textos.

AGAMBEN, G. (2019). Estado de excepción, Ciudad Autónoma de Buenos Aires: Adriana Hidalgo Editora

AGIER, M. (2011). Managing the undesirables. Refugee camps and humanitarian government. Polity Press, Cambridge, UK.

AMNESTY INTERNATIONAL, (2018). Cruel European migration policies leave refugees trapped in Libya with no way out. https:/www.amnesty.org/en/latest/ news/2018/11/cruel-european-migration-policies-leave-refugees-trapped-inlibya-with-no-way-out/

BALZAQ, T. (2008). The external dimension of EU justice and home affairs: tools, processes, outcomes', Centre for European Policy Studies, Working Document No 303. https://www.ceps.eu/ceps-publications/external-dimension-eu-justice-and-ho me-affairs-tools-processes-outcomes/

BAMBRILLA, C. (2015). Brambilla (2015) 'Exploring the Critical Potential of the Borderscapes Concept' Geopolitics, vol. 20, no.1, pp. 14-34. https://doi.org/10.10 80/14650045.2014.884561

BAMBRILLA, C. (2020). 'Revisiting 'Bordering, Ordering and Othering': An Invitation to 'Migrate' Towards A Politics of Hope' Tijdschrift voor Economische en Sociale Geografie, no. 112, pp. 11-17. https://doi.org/10.1111/tesg.12424 
CALHOUM, C. (2013). 'The idea of emergency: humanitarian action and global (dis order' in D. Fassin \& M. Pandolfi eds. Contemporary states of emergency. The Politics of Military and Humanitarian Interventions, Zone Books, Brooklyn, NY.

CAMPA, R. (2015). 'Biopolitica e biopotere. Da Foucault a l'italian theory oltre' Orbis Idearum, vol. 3, no. 1, pp. 125-170.

CASTLES, S. (2004). 'The Factors that Make and Unmake Migration Policies' The International Migration Review, vol. 38, no. 3, pp. 852-884. www.jstor.org/stable/ 27645419. https://doi.org/10.1111/j.1747-7379.2004.tb00222.x

CEAR, (2015). Marruecos: desprotección y vulneración de derechos de las personas migrantes y refugiadas a las puertas de Europa. https://www.cear.es/wp-content/ uploads/2016/11/informe_marruecos_cear_2015_definitivo.pdf

CEAR, (2017). Refugiados y migrantes en España: los muros invisibles tras la frontera sur https://www.cear.es/wp-content/uploads/2018/02/INFORME-FRONTERA-S UR.pdf

CHURRUCA, C. (2019). 'Shrinking protection space through gatekeeping and fencing strategies. The impact of EU's migration control on the protection of asylum seekers and forced migrants at EU's external borders' Spanish yearbook of international law, no. 23, pp. 170-182. https://doi.org/10.17103/sybil.23.9

COLLYER, M. (2019). 'From preventive to repressive: the changing use of development and humanitarianism to control migration' in MITCHELL, K., REECE, J., FLURI, J.L., (Eds). (2019) Handbook on critical geographies of migration, Cheltenham, UK: Edward Elgar Publishing https://doi.org/10.4337/9781786436030

COMMISSION OF THE EUROPEAN COMMUNITIES, (2002). Integrating migration issues in the European union's relations with third countries. Communication from the commission to the council and the European parliament Brussels, 3.12.2002 $\operatorname{COM}(2002) 703$ final https://eur-lex.europa.eu/LexUriServ/LexUriServ.do?uri=C OM:2002:0703:FIN:EN:PDF

COUNCIL OF THE EUROPEAN UNION, (2002).Presidency Conclusions, Seville European Council, 21-22 June 2002, 22 June 2002 https://www.refworld.org/ docid/3f4e45154.html

COUNCIL OF THE EUROPEAN UNION, (2003). Presidency Conclusions, Thessaloniki European Council, 19-20 June 2003, 20 June 2003, available at: https://www. refworld.org/docid/3f532b584.html

COUNCIL OF THE EUROPEAN UNION, (2004). Presidency Conclusions, Brussels European Council, 4-5 November 2004, 8 December 2004, 14292/1/04, available at: https://www.refworld.org/docid/47fdfad90.html

COUNCIL OF THE EUROPEAN UNION, (2005). Presidency Conclusions, Brussels European Council, 15-16 December 2005, 16 December 2005, 15914/05, available at: https://www.refworld.org/docid/43e1ffa24.html 
COUNCIL OF THE EUROPEAN UNION, (2008). Directive 2008/115/EC of the European Parliament and of the Council of 16 December 2008 on common standards and procedures in Member States for returning illegally staying third-country nationals, 16 December 2008, OJ L. 348/98-348/107; 16.12.2008, 2008/115/EC, available at: https://www.refworld.org/docid/496c641098.html

CUTTITTA, P. (2018). 'Repoliticization Through Search and Rescue? Humanitarian NGOs and Migration Management in the Central Mediterranean' Geopolitics, vol. 23, no. 3, pp. 632-660. https://doi.org/10.1080/14650045.2017.1344834

CUTTITTA, P. (2019). 'The central Mediterranean border as a humanitarian space' in $N$ Nyberg Sørensen \& S Plambech (eds), Global Perspectives on Humanitarianism: When human welfare meets the political and security agendas. DIIS REPORT, no. 3, vol. 2019, Danish Institute for International Studies (DIIS), Copenhagen, pp. 15-28. <http://pure.diis.dk/ws/files/2831668/Report_03_Humanitarisme_WEB. pdf?fbclid=IwAR2cWuaMk8uB9xMn_QbQDl-GOGÜi5ZM2fmNGRVXV'2FQI qqBBUL1KDfBxr9I>

DUVA, J, (2007). 'Los sueños amordazados de Osamuyi' El Pais, 17 June 2007. https:// elpais.com/diario/2007/06/17/espana/1182031220_850215.html

ESPOSITO, R. (2005). Immunitas. Protección y negación de la vida. Buenos Aires: Amorrortu editores.

ESPOSITO, R. (2006). Bíos. Biopolitica y filosofia. Buenos Aires: Amorrortu editores.

ESPOSITO, R. (2008). Bios: Biopolitics and Philosophy. University of Minnesota Press, Minneapolis, $\mathrm{MN}$.

ESPOSITO, R. (2012). Communitas. Origen y destino de la comunidad. Buenos Aires: Amorrortu editores.

EUROPEAN COMMISSION, (2005). European Commission, Communication from the Commission to the Council and the European Parliament 'On Regional Protection Programmes' 1 September 2005, COM(2005) 388 final https://eur-lex.europa.eu/ LexUriServ/LexUriServ.do?uri=COM:2005:0388:FIN:EN:PDF

EUROPEAN COMMISSION, (2005b). Communication from the Commission to the Council and the European Parliament, Priority Actions for Responding to the Challenges of Migration: First Follow-Up to Hampton Court, 30 November 2005,

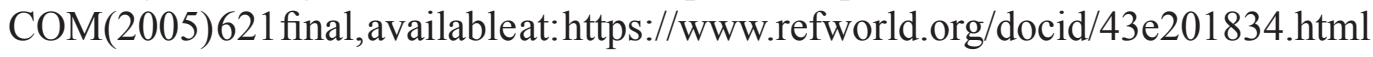

EUROPEAN COMMISSION, (2011). High representative of the European Union for foreign affairs and security policy'Joint communication to the European Parliament and the Council Human Rights and Democracy at the heart of EU external action - towards a more effective approach'. Brussels, 12.12.2011 COM(2011) 886 final. https://eur-lex.europa.eu/LexUriServ/LexUriServ.do?uri=COM:2011:0886:FIN:E $\mathrm{N}: \mathrm{PDF}$

EUROPEAN COMMISSION, (2011b). Communication from the Commission to the European Parliament, the Council, the European Economic and Social Committee 
and the Committee of the Regions 'The Global Approach to Migration and Mobility' 18 November 2011, COM(2011) 743 final,

EUROPEAN COMMISSION, (2015). Communication from the Commission to the European Parliament, the Council, the European Economic and Social Committee and the Committee of the Regions. A European Agenda on Migration, 13 May 2015, COM(2015) 240 https://ec.europa.eu/anti-trafficking/sites/antit rafficking/files/communication_on_the_european_agenda_on_migration_en .pdf

EUROPEAN COMMISSION, (2020). Communication from the commission to the European Parliament, the Council, the European Economic and Social Committee and the Committee of the Regions on a New Pact on Migration and Asylum. Brussels, 23.9.2020 COM(2020) 609 final

EUROPEAN PARLIAMENT, (2005). Official Journal of the European Union, CE 226, C 226 E/228, 15 September 2005 https://eur-lex.europa.eu/legal-content/EN/TXT/ HTML/?uri=CELEX:52004IP0100(01)\&from=ES

EUROPEAN PARLIAMENT, (2005b). Official Journal of the European Union, C 33 E/598, Resolution on Lampedusa, P6_TA(2005)0138, Thursday 14 April 2005. https://eur-lex.europa.eu/resource.html?uri=cellar:ae1c7cb2-7915-4ca6-a1be5174f3fb7057.0005.02/DOC_54\&format=PDF

EUROPEAN PARLIAMENT, (2012). Parliamentary Questions, 19 January 2012. Subject: Death of Idrissa Diallo in the Detention Centre for Foreigners (CIE) in Barcelona. Permanent violation of human rights, mistreatment and repression in Spanish Detention Centres. Question for written answer E-000333/2012 to the Commission Rule 117, Willy Meyer (GUE/NGL) https://www.europarl.europa. eu/doceo/document/E-7-2012-000333_EN.html?redirect

EUROPEAN UNION, (1992). Treaty on European Union (Consolidated Version), Treaty of Maastricht , 7 February 1992, Official Journal of the European Communities C 325/5; 24 December 2002, available at: https://www.refworld.org/docid/3ae6b39 218.html

EUROPEAN UNION, (1999). Council of the European Union, Presidency Conclusions, Tampere European Council, 15-16 October 1999, 16 October 1999. https:// ec.europa.eu/anti-trafficking/eu-policy/tampere-council-conclusions-1999_en

EUROPEAN UNION, (2007). Treaty of Lisbon Amending the Treaty on European Union and the Treaty Establishing the European Community, 13 December 2007, 2007/C 306/01, available at: https://www.refworld.org/docid/476258d32.html

EUROPEAN UNION, (2010). Regulation No 439/2010 of the European Parliament and of the Council of 19 May 2010 establishing a European Asylum Support Office, 19 May 2010, OJ L.132/11-132/28; 29.5.2010, (EU)No 439/2010. https://eurlex.europa.eu/LexUriServ/LexUriServ.do?uri=OJ:L:2010:132:0011:0028:EN :PDF 
EUROPEAN UNION, (2012). Consolidated version of the Treaty on the Functioning of the European Union, 26 October 2012, OJ L. 326/47-326/390; 26.10.2012 https://eur-lex.europa.eu/resource.html?uri=cellar:2bf140bf-a3f8-4ab2-b506fd71826e6da6.0023.02/DOC_1\&format=PDF

FASSIN, D. (2012). Humanitarian reason: a moral history of the present. Berkeley: University of California Press, Berkeley etc.]. https://doi.org/10.1525/ california/9780520271166.001.0001

FASSIN, D. (2016). La razón humanitaria. Una historia moral del tiempo presente, Prometeo Libros, Buenos Aires.

FOUCAULT, M. (2006). Seguridad, territorio, población. Curso de Collège de France (1977-1978). Villa Ballester, Buenos Aires, Argentina: Grafinor S.A.

GADEM, (2018). Côutes et blessures. https://www.lacimade.org/wp-content/uploads/201 8/10/20180927_GADEM_Couts_et_blessures.pdf

GADEM, (2018b). Expulsions Gratuites. https://gallery.mailchimp.com/66ce6606f50d8 fd7c68729b94/files/3690d5cc-2b47-404c-a43d-ca0beeb7e383/20181011_GAD EM_Note_Expulsion_gratuite_VF.pdf

GÓMEZ ISA, F., CHURRUCA MUGURUZA, C., WOUTERS, J., (Eds.). (2018). EU human rights and democratization policies: achievements and challenges (1st ed.). London: Routledge. https://doi.org/10.4324/9781315110769

GRANGE, M., and FLYNN, M. (2014). Immigration Detention in Egypt Global Detention Project. Geneva, Switzerland. https://www.refworld.org/pdfid/54588b174.pdf

HARDT, M. and NEGRI, A. (2009). Imperio. Barcelona: Paidós.

HUMAN RIGHTS WATCH, (2014). Abuse and expelled Ill-Treatment of Sub-Saharan African Migrants in Morocco. https://www.hrw.org/report/2014/02/10/abusedand-expelled/ill-treatment-sub-saharan-african-migrants-morocco

HUMAN RIGHTS WATCH, (2016). Spain Migrants held in poor conditions: automatic detention, obstacles to seeking asylum. https://www.hrw.org/news/2017/07/31/ spain-migrants-held-poor-conditions

HUMAN RIGHTS WATCH, (2019). No Scape from hell: EU Policies Contribute to Abuse of Migrants in Libya. https://www.hrw.org/report/2019/01/21/no-escape-hell/eupolicies-contribute-abuse-migrants-libya

INTERNATIONAL PEACE INSTITUTE, (2016). Learning from the canaries: lessons from the 'cayucos' crises. Desperate migration series no. 1, May 2016. https://reliefweb. $\mathrm{int} /$ sites/reliefweb.int/files/resources/1605_Learning-from-the-Canaries.pdf

KINGSLEY, P. (2014). 'Desperate Syrian refugees risk all in bid to reach Europe' The Guardian. 18 September 2014. http://www.theguardian.com/globaldevelopment/ 2014/sep/18/desperate-syrian-refugees-europe-mediterranean 
LAVENEX, S. (2006). 'Shifting up and out: The foreign policy of European immigration control' West European Politics, vol. 29, no. 2, pp. 329-350. https://doi. org/10.1080/01402380500512684

LAVENEX, S. \& WICHMANN, N. (2009). 'The External Governance of EU Internal Security' Journal of European Integration, vol. 31, no. 1, pp. 83-102. https://doi. org/10.1080/07036330802503932

LAVENEX, S. (2015). 'Multilevelling EU external governance: the role of international organizations in the diffusion of EU migration policies' Journal of Ethnic and Migration Studies, vol. 42, no. 4, pp. 1-17. https://doi.org/10.1080/136918 3X.2015.1102047

LEMERG-PEDERSEN, M. (2012). Externalization and Border-induced Displacement: A critical assessment of the European Borderscapes, $\mathrm{PhD}$ Dissertation. University of Copenhagen.

LEMBERG-PEDERSEN, M. (2015). 'Losing the Right to have rights: EU externalization of borders control' in André, E., Andersen and Lassen, E.M., (Eds). Europe and the Americas: Transatlantic approaches to human rights. Leiden: Brill. pp. 422.

MBEMBE, A. (2011). Necropolitica. España: Melusina. https://doi.org/10.1007/978-3531-92807-4 3

MEDICINS SANS FRONTIERS, (2005). Violence et immigration Rapport sur l'immigration d'origine subsaharienne en situation irrégulière au Maroc. MSF Espagne. Enquête réalisée par la section espagnole de Médecins Sans Frontières, rendue publique le 29 septembre 2005. https://www.msf.fr/sites/default/files/200509-29-MSFE.pdf

MEISSNER, V. (2017). The European Border and Coast Guard Agency Frontex beyond Borders - the Effect of the Agency's External Dimension (December 10, 2017). TARN Working Paper Series 16/2017, December 2017, Available at SSRN: https:// ssrn.com/abstract=3085529 or https://doi.org/10.2139/ssrn.3085529

MEZZADRA, S. (2005). Derecho de fuga. Migraciones, ciudadanía y globalización Madrid: Traficantes de sueños.

MEZZADRA, S. and NEILSON, B. (2017). La frontera como método. Madrid: Traficantes de sueños.

MORENO-LAX, V. and LEMBERG-PEDERSEN, M. (2019) Border-induced displacement: The ethical and legal implications of distance-creation through externalization. QIL Questions of International Law, Zoom-in 56 (2019) 5-33

MORENO-LAX, V. (2020). EU external dimension policy and the protection of Human Rights. European Parliament. https://www.europarl.europa.eu/thinktank/en/ document.html?reference=EXPO_IDA\%282020\%29603512 
NARVAEZ, J.C., (1988). 'Un marroquí muerto y 18 desaparecidos al volear una lancha en el estrecho' El País, 2 Noviembre 1988 https://elpais.com/diario/1988/11/02/ espana/594428418_850215.html

ORGAZ ALONSO, C. (2018). Emergencia del dispositivo deportador en Europa y su generalización en el caso español: representaciones y prácticas en torno a los Centros de Internamiento para Extranjeros (CIE). PhD Dissertation. Universidad Complutense de Madrid.

PALLISTER-WILKINS, P. (2015). 'The Humanitarian Politics of European Border Policing: Frontex and Border Police in Evros' International Political Sociology, vol. 9, no. 1, pp. 53-69. https://doi.org/10.1111/ips.12076

PAPADOPOULOS, D., STEPHENSON, N. and TSIANOS, V., (2008). Escape Routes: Control and Subversion in the 21st Century. London: Pluto.

PARKER and VAUGHAN-WILLIAMS, (2012). 'Critical Border Studies: Broadening and Deepening the 'Lines in the Sand' Agenda' Geopolitics, vol. 17, no. 4, pp. 727-733. https://doi.org/10.1080/14650045.2012.706111

RODRIGUEZ, P. (2013). 'Una protesta por la última muerte en el CIE de Barcelona sirve para denunciar la deportación de testigos clave' Eldiario.es, 9 december 2013. https://www.eldiario.es/catalunya/concentracion-cie-barcelona-denunciardeportacion_1_5123548.html

RTVE 2020 'España, Italia, Grecia y Malta piden a la UE más solidaridad y que se repartan los migrantes entre los países miembros' RTVE.es, 25 November 2020 https:/www.rtve.es/noticias/20201125/espana-italia-grecia-malta-piden-ue-massolidaridad-nuevo-plan-migracion-asilo/2058489.shtml

THE GUARDIAN, (2015). 'UN says 800 migrants dead in boat disaster as Italy launches rescue of two more vessels', The Guardian, 20 April 2015.https://www. theguardian.com/world/2015/apr/20/italy-pm-matteo-renzi-migrant-shipwreckcrisis-srebrenica-massacre

TICKTIN, M. (2011). Casualties of care: immigration and politics of humanitarianism in France. University of California Press, Berkeley, CA, USA. https://doi. org/10.1525/9780520950535

UNHCR, (2002). Agenda for Protection. https://www.unhcr.org/protect/PROTECTION /3e637b194.pdf

UNHCR,(2005).'Italy:UNHCRdeeplyconcernedaboutLampedusadeportationsofLibyans' UNHCR, 18 March 2005. https://www.unhcr.org/news/briefing/2005/3/423ab71a4/ italy-unhcr-deeply-concerned-lampedusa-deportations-libyans.html

VAUGHAN-WILLIAMS, N. (2017a). Border politics: the limits of sovereign power. Edinburgh: University Press.

VAUGHAN-WILLIAMS, N. (2017b). Europe's Border Crisis: Biopolitical Security and Beyond. Oxford University Press DOI:10.1093/acprof:oso/9780198747024.001.0 001 
WALTERS, W. (2011). 'Foucault and Frontiers: Notes on the Birth of the Humanitarian Border' in Governmentality: Current Issues and Future Challenges, BRÖCKLING, U., KRASMANN, S., and LEMKE, T. (2011). New York: Routledge, pp. 138164.

WEYZMAN, E. 2017, The least of all possible evils. A short history of humanitarian violence, Verso, London New York.

ZETTER, R. (2014). Forced Migrants: A State of the Art Report of Concepts, Challenges and Ways Forward. Refugees Studies Center. Oxford University. https://www. rsc.ox.ac.uk/publications/protecting-forced-migrants-a-state-of-the-art-report-ofconcepts-challenges-and-ways-forward

Received: December $12^{\text {th }} 2021$

Accepted: March $1^{\text {st }} 2021$ 